\title{
Evaluation of the stability of vancomycin solutions at concentrations used in clinical services
}

\author{
Morgane Masse, Stéphanie Genay, Anthony Martin Mena, Natacha Carta, \\ Damien Lannoy, Christine Barthélémy, Bertrand Décaudin, Pascal Odou
}

\begin{abstract}
- Additional material is published online only. To view please visit the journal online (http://dx.doi.org/ 10.1136/ejhpharm-2019002076).

Univ. Lille, CHU Lille, ULR 7365-GRITA-Groupe de Recherche sur les formes Injectables et les Technologies Associées, F-59000 Lille, France
\end{abstract}

\section{Correspondence to} Dr Morgane Masse, Faculty of Pharmacy, University of Lille, Lille 59000, France; morgane. masse@univ-lille.fr

Received 26 August 2019 Revised 25 December 2019 Accepted 31 December 2019 Published Online First

5 February 2020

EAHP Statement 3: Production and Compounding.

\section{Check for updates}

(C) European Association of Hospital Pharmacists 2020. No commercial re-use. See rights and permissions. Published by BMJ.

To cite: Masse M, Genay S, Martin Mena A, et al. Eur J Hosp Pharm 2020;27:e87-e92.

\section{INTRODUCTION}

Vancomycin hydrochloride is an antibiotic belonging to the glycopeptide family and acts by inhibiting the synthesis of the peptidoglycan wall. This antibiotic is active against Gram-positive aerobic and anaerobic bacteria ${ }^{12}$ and is commonly used in hospitals to treat serious infections. ${ }^{34}$

Vancomycin has slow bactericidal time-dependent activity and can be administered by continuous or intermittent intravenous infusion. In France, administering vancomycin by continuous infusion over 24 hours is recommended. ${ }^{56}$

The Summary of Product Characteristics (SmPC) recommends reconstituting a $1 \mathrm{~g}$ vial with $20 \mathrm{~mL}$ of water for injection (WFI), then diluting it in $100 \mathrm{~mL}$ of saline solution. The amount of vancomycin to treat an adult infection is superior to $1 \mathrm{~g}$ and so the volume administered can be higher than $100 \mathrm{~mL}$. This volume must be limited in children or in patients on water restriction, such as those suffering from hyponatraemia and cardiovascular diseases or are in intensive care. ${ }^{7}$

Some studies on vancomycin stability have already been performed. Solutions at 5 and $10 \mathrm{mg} / \mathrm{mL}$ were stable for 58 days at $+4^{\circ} \mathrm{C}$ in $100 \mathrm{~mL}$ polyvinyl chloride (PVC) infusion bags with no specification with regard to protection from light. ${ }^{8}$ Vancomycin was stable at $5 \mathrm{mg} / \mathrm{mL}$ in PVC bags for 48 hours at $+22^{\circ} \mathrm{C}$ without protection from light and for 7 days at $+4^{\circ} \mathrm{C}$ with protection from light. ${ }^{9}$ Raverdy et al ${ }^{10}$ examined the stability of vancomycin diluted in 5\% dextrose at high concentration $(83 \mathrm{mg} / \mathrm{mL})$ and was stable for 72 hours at $+37^{\circ} \mathrm{C}$.

However, none of these studies reflects real infusion conditions as vancomycin is usually administered at $30 \mathrm{mg} / \mathrm{kg} /$ day. ${ }^{11}{ }^{12}$ In practice, clinical services infuse vancomycin into electric syringe pumps using $50 \mathrm{~mL}$ (for adults) or $20 \mathrm{~mL}$ (for children) syringes. No stability study has yet been performed for such concentrations, in 50 or $20 \mathrm{~mL}$ syringes, at room temperature, nor has the reconstitution procedure ${ }^{13}$ been assessed. SmPC recommends reconstitution in WFI, then dilution in saline solution. However, in clinical units, vancomycin is often reconstituted and diluted in saline solution.

The aim of this work was therefore to study vancomycin stability in syringes and assess its use $(\mathrm{pH}$, osmolality, number of particles) during a continuous 24-hour infusion with and without inline filters at four concentrations-25, 40, 60 and $80 \mathrm{mg} / \mathrm{mL}$-reconstituted in two solvents (WFI and saline solution) and diluted in saline solution.

\section{MATERIALS AND METHODS}

\section{Chemicals}

The commercialised vancomycin used in this study came in lyophilised powder form $(500 \mathrm{mg}$ or $1 \mathrm{~g}$ vancomycin hydrochloride with the following excipients: mannitol, $0.5 \mathrm{~N}$ sodium hydroxide and $0.5 \mathrm{~N}$ hydrochloric acid) from Sandoz (LevalloisPerret, France). Vancomycin was reconstituted with WFI (Baxter, Guyancourt, France) or saline solution ( $0.9 \%$ sodium chloride; Baxter) and diluted in the same saline solution. European Pharmacopoeia (EP) standard vancomycin powder (Code: V0045000, Council of Europe, Strasbourg, France) was used to validate the assay method in WFI to reach a vancomycin concentration of $400 \mu \mathrm{g} / \mathrm{mL}$. To perform the mobile phase, acetonitrile (high-performance liquid chromatography (HPLC) gradient grade; VWR Chemicals, Fontenay-sous-Bois, France), phosphate buffer (potassium dihydrogen phosphate; Merck, Calais, France), ultrapure water (Purelab Classic Elga System, Veolia, Wasquehal, France) and orthophosphoric acid (Merck) were used.

For the degradation protocol, 35\% hydrochloric acid (Merck), 37\% sodium hydroxide (VWR Chemicals) and $1 \%$ hydrogen peroxide (Gilbert, Hérouville-Saint-Clair, France) were used.

\section{Stability-indicating method with liquid chromatography}

An HPLC system (Shimadzu, Noisiel, France) was used to quantify vancomycin. It was equipped with a degassing DGU-20A3R unit, two LC-20ADXR solvent delivery units (Prominence UFLCXR series), an SIL-20ACXR autosampler, a CTO-20AC column oven and an SPD-M20A photodiode array detector (DAD).

The mobile phase, adapted from Jesús Valle et al's method ${ }^{14}(8: 92, \mathrm{v} / \mathrm{v})$, was composed of acetonitrile and phosphate buffer $(6.8 \mathrm{~g} / \mathrm{L})$ diluted in ultrapure water and adjusted to $\mathrm{pH} 4$ with orthophosphoric acid. The flow rate was fixed at $1.2 \mathrm{~mL} /$ min and each run lasted $10 \mathrm{~min}$. Separation of vancomycin was carried out on a Kinetex C18 column $(100 \times 4.6 \mathrm{~mm}$ id, $2.6 \mu \mathrm{m})$ preceded by a C18 cartridge guard $(4.6 \mathrm{~mm})$ (Phenomenex, Le Pecq, France). The injection volume was $20 \mu \mathrm{L}$ and quantification was performed at $280 \mathrm{~nm}$.

The degradation protocol complied with the SFPC/Gerpac methodological guidelines. ${ }^{15}$ To obtain about $20 \%$ degradation of vancomycin, the following conditions were used: heat $\left(+80^{\circ} \mathrm{C}\right.$, for $300 \mathrm{~min})$, acidity $\left(+20^{\circ} \mathrm{C}, 4 \mathrm{~N}\right.$ hydrochloric acid, for 2 hours), basicity $\left(+20^{\circ} \mathrm{C}, 4 \mathrm{~N}\right.$ sodium 
Table 1 Protocol for obtaining clinical concentrations of vancomycin

\begin{tabular}{lllll}
\hline $\begin{array}{l}\text { Vancomycin } \\
\text { concentration } \\
(\mathrm{mg} / \mathrm{mL})\end{array}$ & $\begin{array}{l}\text { Vancomycin } \\
\text { dosage used } \\
(\mathrm{g})\end{array}$ & $\begin{array}{l}\text { Number } \\
\text { of vials } \\
\text { used }\end{array}$ & $\begin{array}{l}\text { Reconstitution } \\
\text { volume of } \\
\text { WFI or saline } \\
\text { solution/vial } \\
(\mathrm{mL})\end{array}$ & $\begin{array}{l}\text { Added dilution } \\
\text { volume of saline } \\
\text { solution }(\mathrm{mL}) \\
\text { to obtain final } \\
\text { volume (volume) }\end{array}$ \\
\hline 25 & 0.5 & 1 & 10 & $10(20 \mathrm{~mL})$ \\
40 & 1 & 2 & 20 & $10(50 \mathrm{~mL})$ \\
60 & 1 & 3 & 16 & $2(50 \mathrm{~mL})$ \\
80 & 1 & 4 & 12 & $2(50 \mathrm{~mL})$ \\
\hline
\end{tabular}

WFI, water for injection.

hydroxide, for $15 \mathrm{~min})$ and oxidation $\left(+20^{\circ} \mathrm{C}, 1 \%\right.$ hydrogen peroxide, for 3 hours). The vancomycin solution was diluted to a theoretical concentration of $100 \mu \mathrm{g} / \mathrm{mL}$, regardless of the degradation conditions tested. Samples were then analysed by HPLC-DAD.

To validate the HPLC-DAD method, working solutions were prepared and diluted in WFI to reach concentrations ranging from 40 to $200 \mu \mathrm{g} / \mathrm{mL}$ (40, 60, 80, 100, 120, 140 and $200 \mu \mathrm{g} /$ $\mathrm{mL})$. Validation was carried out on three consecutive days by determining the following parameters: specificity, linearity, limits of detection (LOD) and limits of quantification (LOQ). ${ }^{16} 17$

To assess chemical stability, vancomycin concentration was expressed as the ratio, in percentage, of the concentration measured at sampling times to the initial concentration in the syringe before infusion $\left(\mathrm{Ct} / \mathrm{C}_{0}, \%\right)$. The solution was considered stable if the concentration remained $\geq 90 \%$ of $\mathrm{C}_{0}$. The cumulative amount over 24 hours was also calculated to appreciate the amount of vancomycin administered. The percentage loss corresponds to the following equation:

with the following theoretical amounts of vancomycin: $4 \mathrm{~g}$, $3 \mathrm{~g}, 2 \mathrm{~g}$ or $500 \mathrm{mg}$.

\section{Preparation of vancomycin syringes}

For each studied concentration, two reconstitution solvents were used: WFI and saline solution. Vials were reconstituted either with WFI and diluted in saline solution, following SmPC recommendations, or reconstituted and diluted in saline solution, following current practice in our clinical units. The protocol is summarised in table 1.

All samples were prepared and standardised by the same experienced operator, at $25^{\circ} \mathrm{C} \pm 2^{\circ} \mathrm{C}$. Vials were reversed 10 times to mix the solvent homogeneously, then were left for 1 hour to obtain complete dissolution of the lyophilisate. They were then shaken again before preparing the polypropylene syringes (20 or $50 \mathrm{~mL}$ ) (Becton-Dickinson, Le Pont-de-Claix, France) and starting the infusion through or without an inline filter.

\section{Infusion protocol}

Vancomycin stability was tested during continuous infusion through a polyethylene infusion line (length $=150 \mathrm{~cm}$ and internal diameter $=1 \mathrm{~mm}$, reference: PE1155.15; Vygon, France). Room temperature was set at $25^{\circ} \mathrm{C} \pm 2{ }^{\circ} \mathrm{C}$. Solutions were infused by syringe pumps (Orchestra, Fresenius Kabi, Sèvres, France). Two parallel experiments were carried out. The first experiment was with inline filters in two categories: (1) with a $0.2 \mu \mathrm{m}$ inline filter, reference NEO96E, for paediatric patients with a $25 \mathrm{mg} /$ $\mathrm{mL}$ vancomycin solution infused at $0.8 \mathrm{~mL} /$ hour and (2) with a $0.2 \mu \mathrm{m}$ inline filter, reference AEFF1NTE, for adult patients with $40-60$ and $80 \mathrm{mg} / \mathrm{mL}$ vancomycin solutions infused at $2 \mathrm{~mL} /$ hour (Pall Corporation, Saint-Germain-en-Laye, France).
The filters positioned at the end of the infusion line can sustain flow rates of up to $100 \mathrm{~mL} /$ hour and $540 \mathrm{~mL} /$ hour, respectively. The second experiment was performed under the same flow rate conditions but without an inline filter. The flow rate was constant for 24 hours to ensure total infusion of the syringe.

Visual observation was made during the infusion and sample solutions were collected at the egress of the infusion line every 2 hours. If no particle was observed, vancomycin level was measured by HPLC-DAD ( $\mathrm{n}=5$ syringes). All samples were diluted in saline solution to obtain a theoretical concentration of $100 \mu \mathrm{g} / \mathrm{mL}$. No degradation products were found in the chromatograms obtained during the infusion protocol.

\section{Osmolality and $\mathrm{pH}$ measures}

Osmolality (3300 Micro-Osmometer, Advanced Instruments, Norwood, USA) and pH (SB70P Symphony, VWR International, Fontenay-sous-Bois, France) were measured for each vancomycin solution at the onset and end of infusion $(n=3)$.

\section{Particulate counting}

Vancomycin solutions in syringes were analysed using a particle counting system (APSS-2000, Particle Measuring Systems, Dourdan, France) following Monograph 2.9.19 of the EP. For each infusion condition, three $5 \mathrm{~mL}$ samples from three syringes were analysed using the light obscuration counter $(n=9)$ at time 0 (T0) and at 24 hours (T24). The number of particles $\geq 10 \mu \mathrm{m}$ and $\geq 25 \mu \mathrm{m}$ should not exceed 6000 and 600 particles per syringe, respectively. ${ }^{18}$

\section{Statistical analysis}

The Mann-Whitney U test compared the following filtered and unfiltered measurements: cumulative amount with both reconstitution solvents at T24, and the number of particles, $\mathrm{pH}$ and osmolality at T0 and T24. Statistical testing was done at the twotailed $\alpha$ level of 0.05 . Data were analysed using Xlstat software (Microsoft Excel, V.16.15, Addinsoft, Paris, France).

The results for $\mathrm{pH}$, osmolality and number of particles were expressed as median (IQR).

\section{RESULTS}

\section{Stability-indicating method and HPLC-DAD validation}

Under heat degradation, two degradation peaks were obtained (retention time $(\mathrm{RT})=1.25 \mathrm{~min}$ and $2.80 \mathrm{~min}$ ); under acidic and basic degradations, one peak at $5.00 \mathrm{~min}$ and $1.25 \mathrm{~min}$, respectively, was obtained, whereas no peak was obtained in oxidative degradation conditions. All the degradation peaks presented different RTs from that of vancomycin, which was $3.08 \mathrm{~min}$. No degradation products were detected on the chromatograms during the stability study.

Dosage was validated using a linear regression model. Good linearity was shown over the whole concentration range $\left(40-200 \mu \mathrm{g} / \mathrm{mL}, \mathrm{r}^{2}=0.993\right)$. LOD and LOQ were $11.87 \mu \mathrm{g} / \mathrm{mL}$ and $23.73 \mu \mathrm{g} / \mathrm{mL}$, respectively. The measured concentrations were back-calculated using the selected calibration model, and relative bias (trueness) was calculated. Relative bias was inferior to $1 \%$ over the whole calibration range (online supplementary data, table 4).

\section{Chemical stability during the 24-hour infusion}

The results demonstrated stability during the 24-hour infusion: the percentage of vancomycin concentration remained over $90 \%$ (figure 1). However, for vancomycin at $80 \mathrm{mg} / \mathrm{mL}$ reconstituted and diluted in saline solution, visible particles were observed in 


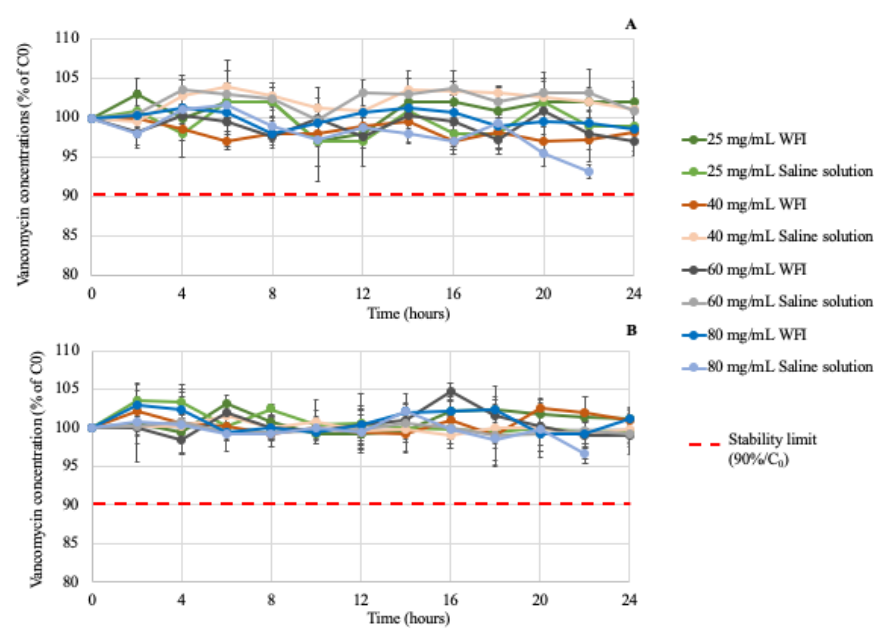

Figure 1 Stability profiles of vancomycin syringes during the 24-hour infusion at $+25^{\circ} \mathrm{C}(A)$ with inline filters and (B) without inline filters $(n=5)$. Data are presented as mean \pm SD. WFI, water for injection.

syringes after 22 hours, so sample dosage at T24 was not carried out.

The cumulative amount of vancomycin in all syringes is shown in table 2.

\section{Osmolality and $\mathrm{pH}$ values}

The median (IQR) osmolality was 19 (12) mOsmol/kg and 292 (1) $\mathrm{mOsmol} / \mathrm{kg}$ for pure WFI and saline solution, respectively. For vancomycin reconstituted with WFI, osmolality was very low for solutions at 40-60 and $80 \mathrm{mg} / \mathrm{mL}$ (table 3); with saline solution, osmolality was closer to blood osmolality. Osmolality was stable during infusion and there was no statistical difference between filtered and non-filtered vancomycin solutions.

The median (IQR) $\mathrm{pH}$ of pure WFI and saline solution was 5.10 (1) and 5.61 (1), respectively. $\mathrm{pH}$ was stable during infusion for all vancomycin solutions and was not statistically different between filtered and non-filtered vancomycin solutions $(\mathrm{p}>0.077)$.

\section{Particulate counting}

The number of particles $\geq 10 \mu \mathrm{m}$ for each vancomycin solution filtered or not at T0 and T24 is reported in figure 2. All solutions without an inline filter contained more than 6000 particles $\geq 10 \mu \mathrm{m}$ per syringe and so were not compatible with Monograph 2.9.19 of the EP and must not be administered to patients. With inline filters, only vancomycin solutions at 25 and $40 \mathrm{mg} /$ $\mathrm{mL}$ contained fewer than 6000 particles per syringe.

The number of particles $\geq 25 \mu \mathrm{m}$ for each vancomycin solution filtered or not at T0 and T24 is reported in figure 3 . All syringes contained fewer than 600 particles $\geq 25 \mu \mathrm{m}$ per syringe. ${ }^{18}$ The number of particles increased according to vancomycin concentrations.

\section{DISCUSSION}

As previously mentioned, several studies ${ }^{7-10}$ have been conducted on physicochemical vancomycin stability but at low concentrations or in trials that do not reflect current use in care units. All published studies have been performed on solutions stocked in containers rather than in continuous infusion, with sampling at the end of the infusion line. Moreover, none has dealt with the particulate load administered to the patient. In this study, measurements of $\mathrm{pH}$, osmolality, physical and chemical stability, and number of particles, with and without filter, were all carried out at different and higher concentrations compared with previously published stability studies. ${ }^{89}$

As for $\mathrm{pH}$ measurement, there was no difference at $\mathrm{T} 0$ and T24. Galanti et $a l^{8}$ showed a significant increase in $\mathrm{pH}$ for vancomycin solutions at 5 and $10 \mathrm{mg} / \mathrm{mL}$ after storage at $+4^{\circ} \mathrm{C}$ for 58 days. However, no data were provided for 24 hours at ambient temperature. Godet et $a l^{7}$ found a $\mathrm{pH}$ of $3.17 \pm 0.01$ at $41.66 \mathrm{mg} / \mathrm{mL}$, which is close to ours at $40 \mathrm{mg} / \mathrm{mL}$, with or without an inline filter (3.38 (1) vs 3.43 (3)). Acidic $\mathrm{pH}$ is not responsible for vancomycin toxicity. ${ }^{19}$ Our $\mathrm{pH}$ values were therefore compatible with patient administration.

The osmolality study indicated that the reconstituted solutions with WFI (as recommended in $\mathrm{SmPC}^{20}$ at $40-60$ and $80 \mathrm{mg} / \mathrm{mL}$ ) remained very hypotonic in $50 \mathrm{~mL}$ syringes, and consequently could not be injected to patients due to an osmolality inferior to $154 \mathrm{mOsmol} / \mathrm{kg}^{21}$ Infusion of hypotonic solutions is associated with an increase in hyponatraemia ${ }^{22}$ and can lead to cellular necrosis. Nevertheless, for syringes with $25 \mathrm{mg} / \mathrm{mL}$ concentration, the solution remained hypotonic, although osmolality was superior to the above threshold, indicating that they should be administered with caution.

All vancomycin solutions reconstituted and diluted with saline solution were isotonic to blood (table 3). Our osmolality values were therefore compatible with patient administration, although

Table 2 Cumulative amount of vancomycin infused over 24 hours at $25^{\circ} \mathrm{C}$ ( $\mathrm{n}=5$ syringes), infused at $0.8 \mathrm{~mL} /$ hour for vancomycin syringes at $25 \mathrm{mg} /$ $\mathrm{mL}$ and at $2 \mathrm{~mL} /$ hour for vancomycin syringes at $40-60$ and $80 \mathrm{mg} / \mathrm{mL}$

\begin{tabular}{|c|c|c|c|c|c|c|}
\hline \multirow{3}{*}{$\begin{array}{l}\text { Vancomycin concentration }(\mathrm{mg} / \\
\mathrm{mL})\end{array}$} & \multirow[b]{3}{*}{ Solvent for reconstitution } & \multirow{2}{*}{\multicolumn{2}{|c|}{ Cumulative quantity (mg) at 24 hours, median (IQR) (\% loss \pm SD) }} & \multicolumn{3}{|l|}{ P value } \\
\hline & & & & \multicolumn{2}{|c|}{$\begin{array}{l}\text { WFI vs saline } \\
\text { solution }\end{array}$} & \multirow[b]{2}{*}{$\mathrm{F}$ vs $\mathrm{N}$} \\
\hline & & With filter & Without filter & $\mathrm{F}$ & NF & \\
\hline \multirow[t]{2}{*}{25} & WFI & $452(2)(6.2 \pm 0.8)$ & $444(5)(7.1 \pm 0.6)$ & 0.063 & 0.905 & 0.071 \\
\hline & Saline solution & $447(2)(7.1 \pm 0.5)$ & $448(4)(7.1 \pm 1.6)$ & & & 0.690 \\
\hline 40 & WFI & $1663(5)(13.5 \pm 0.5)$ & $1662(4)(13.4 \pm 0.1)$ & $0.012^{*}$ & $0.008^{*}$ & 0.802 \\
\hline 60 & Saline solution & $2531(4)(12.1 \pm 0.4)$ & $2550(1)(11.5 \pm 1.1)$ & & & $0.012^{*}$ \\
\hline \multirow[t]{2}{*}{80} & WFI & $3314(4)(13.7 \pm 0.1)$ & $3284(1)(14.4 \pm 0.3)$ & NA & NA & $0.012^{*}$ \\
\hline & Saline solution & NA & NA & & & NA \\
\hline
\end{tabular}




\section{Original research}

Table 3 Evolution of osmolality for each vancomycin condition ( $n=3$ syringes)

\begin{tabular}{|c|c|c|c|c|c|c|c|}
\hline \multirow{2}{*}{$\begin{array}{l}\text { Vancomycin concentration (mg/ } \\
\mathrm{mL})\end{array}$} & \multirow[b]{2}{*}{ Solvent for reconstitution } & \multicolumn{3}{|c|}{ With filter (mOsmol/kg) } & \multicolumn{3}{|c|}{ Without filter (m0smol/kg) } \\
\hline & & TO & T24 & $P$ value & T0 & T24 & $P$ value \\
\hline \multirow[t]{2}{*}{25} & WFI & $176(1)$ & $177(1)$ & 0.800 & $174(1)$ & $175(3)$ & 0.800 \\
\hline & Saline solution & $319(2)$ & $324(2)$ & 0.200 & 319 (3) & $314(2)$ & 0.600 \\
\hline \multirow[t]{2}{*}{40} & WFI & $95(1)$ & $98(1)$ & 0.200 & $92(2)$ & $91(1)$ & 0.800 \\
\hline & Saline solution & $323(1)$ & $326(2)$ & 0.300 & $326(2)$ & $327(1)$ & 0.700 \\
\hline \multirow[t]{2}{*}{60} & WFI & $74(1)$ & $76(1)$ & 0.300 & $73(1)$ & $74(2)$ & 1.000 \\
\hline & Saline solution & $351(2)$ & $354(1)$ & 0.600 & $354(2)$ & $357(1)$ & 0.100 \\
\hline \multirow[t]{2}{*}{80} & WFI & $72(1)$ & $76(1)$ & 0.100 & $72(1)$ & $75(1)$ & 0.072 \\
\hline & Saline solution & $349(1)$ & $352(1)$ & 0.072 & $352(1)$ & $350(2)$ & 0.300 \\
\hline
\end{tabular}

Data are presented as median (IQR).

T0, at time 0; T24, at 24 hours; WFI, water for injection.

the preparation did not follow SmPC recommendations. Hence, it is important to choose publications studying reconstitution and dilution in saline solution for vancomycin infusion by syringe. ${ }^{7}$

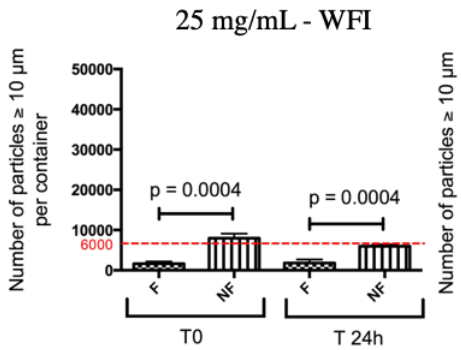

$25 \mathrm{mg} / \mathrm{mL}$ - saline solution

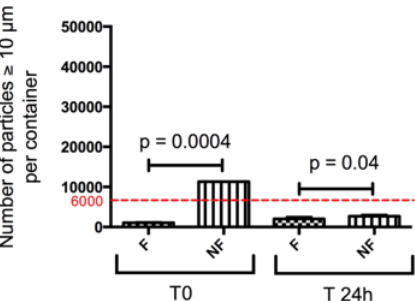

$40 \mathrm{mg} / \mathrm{mL}$ - WFI

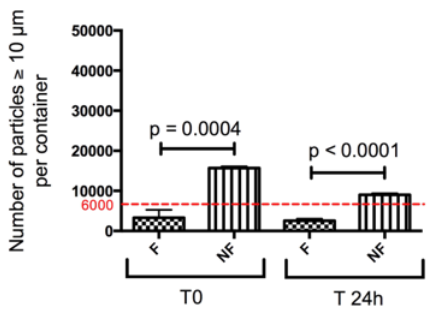

$40 \mathrm{mg} / \mathrm{mL}$ - saline solution

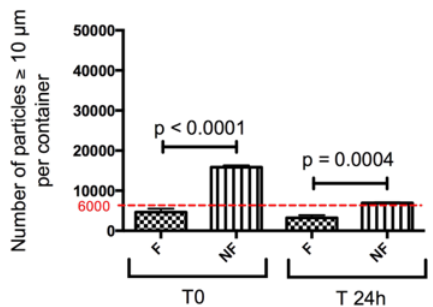

$60 \mathrm{mg} / \mathrm{mL}-$ WFI

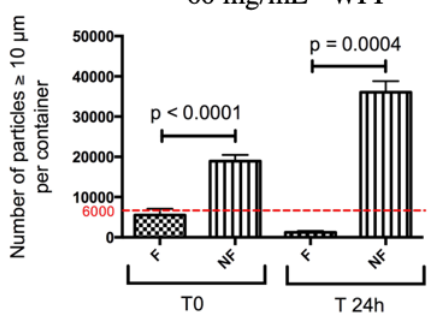

$60 \mathrm{mg} / \mathrm{mL}$ - saline solution

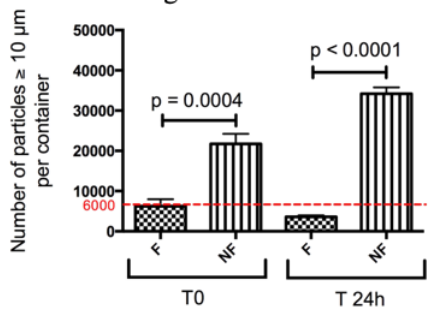

$80 \mathrm{mg} / \mathrm{mL}$ - WFI
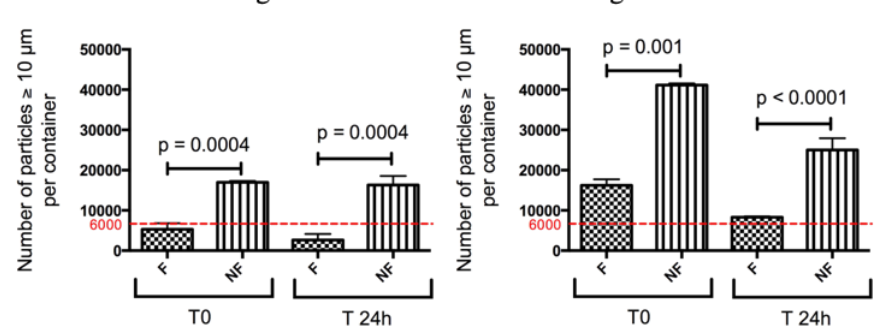

Figure 2 Number of particles $\geq 10 \mu \mathrm{m}$ contained in vancomycin solutions $(n=9)$. F, filtered; NF, non-filtered; T0, at time 0; T24h, at 24 hours; WFI, water for injection.

All vancomycin solutions were physically stable during a 24-hour infusion, except for $80 \mathrm{mg} / \mathrm{mL}$ reconstituted and diluted in saline solution. Indeed, visible particles appeared in syringes

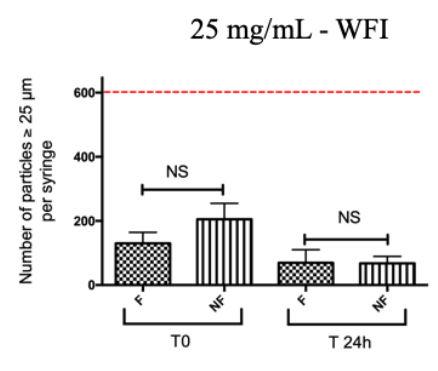

$40 \mathrm{mg} / \mathrm{mL}$ - WFI

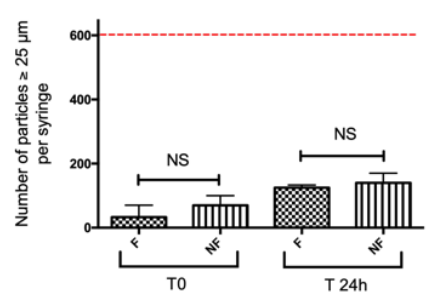

$60 \mathrm{mg} / \mathrm{mL}-\mathrm{WFI}$

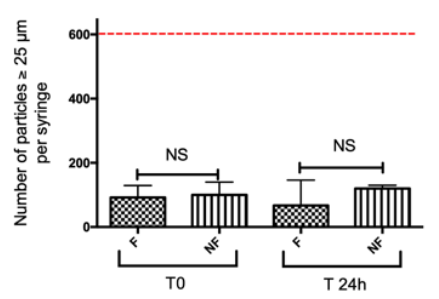

$80 \mathrm{mg} / \mathrm{mL}-$ WFI

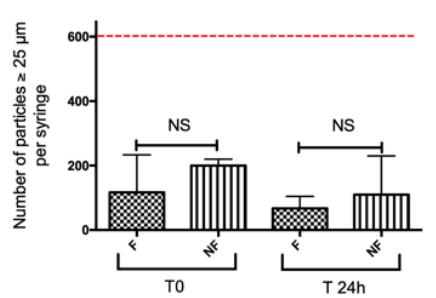

Figure 3 Number of particles $\geq 25 \mu \mathrm{m}$ contained in vancomycin solutions $(n=9)$. F, filtered; NF, non-filtered; T0, at time 0; T24h, at 24 hours; WFI, water for injection. 
between the $22^{\text {nd }}$ and $24^{\text {th }}$ hour of infusion at $25^{\circ} \mathrm{C} \pm 2^{\circ} \mathrm{C}$. After 24 hours at room temperature, with high concentrations, a gel formation was observed in the syringes. This can be explained by the presence of mannitol as an excipient.

The percentage loss of a cumulative amount of vancomycin during a 24-hour infusion was statistically different for the two solvents (WFI and saline solution) at $40-60$ and $80 \mathrm{mg} / \mathrm{mL}$ solutions (table 2). The cumulative amount of vancomycin was also statistically different between filtered and non-filtered 60 and $80 \mathrm{mg} / \mathrm{mL}$ solutions. However, these differences $(<15 \%)$ were not clinically relevant and could be considered as equivalent. This might be due to the reconstitution of vancomycin lyophilisate in marketed products that may contain $85 \%-115 \%$ of the indicated quantity of active drug. However, the loss was greater for higher concentrations of vancomycin $(60$ and $80 \mathrm{mg} / \mathrm{mL})$, suggesting a lyophilisate dissolution problem, as syringes were uniformly prepared. Indeed, $\mathrm{SmPC}^{20}$ recommends $20 \mathrm{~mL}$ for $1 \mathrm{~g}$ of vancomycin, which is rarely practised in care units.

For all vancomycin solutions (figures 2 and 3), the results of particulate counting showed a marked presence of subvisible particles, and for $80 \mathrm{mg} / \mathrm{mL}$ in saline solution visible particles were observed. No other published study has considered particle counting, although it seems to be essential when using an intravenous solution. Vancomycin syringes containing more than 6000 particles $\geq 10 \mu \mathrm{m}$ must not be administered to patients as they can have a clinical impact: central venous catheter obstruction, potentially fatal embolism, and other forms of clinical organ failure such as systemic inflammatory response syndrome and pulmonary toxicity. ${ }^{23}$ The number of particles $\geq 25 \mu \mathrm{m}$ was in all cases under the threshold (600 particles), regardless of the concentration considered and the solvent used.

No non-filtered vancomycin solutions, regardless of the concentrations considered, concorded with the EP with regard to particles $\geq 10 \mu \mathrm{m}$, whereas it was satisfactory for particles $\geq 25 \mu \mathrm{m}$. Although the EP refers to postproduction quality control, particle counting after 24 hours of infusion reflects the particulate load administered to the patient during infusion.

With a $0.2 \mu \mathrm{m}$ inline filter, particulate load was minimised. Only vancomycin solutions at 25 and $40 \mathrm{mg} / \mathrm{mL}$ reconstituted in all solvents with filter, compliant with Monograph 2.9.19 of the $\mathrm{EP}^{18}$ could be administered to patients. However, due to osmolality values, $40 \mathrm{mg} / \mathrm{mL}$ solutions reconstituted with WFI should not be administered. For 60 and $80 \mathrm{mg} / \mathrm{mL}$ solutions, the high number of particles was certainly due to precipitation occurring beyond the filter as well as solubility problems (drug and/or excipients). Particle formation could be at the origin of vancomycin toxicity as reported by Luque et $a l,{ }^{25}$ who found aggregates of nanospheric vancomycin which could result in acute renal failure. Their results were confirmed by immunohistochemistry in mice and showed the impact of vancomycin particles on kidney toxicity.

With our results, some complementary studies are required to establish the precise nature and origin of particles (vancomycin, mannitol). Indeed, different specialties may produce different particulate contamination, ${ }^{26}$ which is affected by numerous parameters, such as the quality of the active substance, excipients, solvents, conditions, manufacturing processes and clinical preparation practices. An optimised protocol can reduce vancomycin dosage variations and enable homogeneous preparations. ${ }^{27}$ Indeed, variations in vancomycin dosage were due to the reconstitution solvent (saline solution) and the non-systematic practice of homogeneously mixing the lyophilisate. ${ }^{27}$

From this study, recommendations can be made for vancomycin infusion in care units. A $50 \mathrm{~mL}$ syringe should not contain
What this paper adds

What is already known on this subject

- Vancomycin is a broad-spectrum antibiotic widely used in hospitals, and is used at a concentration of up to $30 \mathrm{mg} / \mathrm{kg}$ and infused continuously over 24 hours.

- Currently, stability studies alone do not reflect the practical conditions of vancomycin use in care services.

- The intravenous infusion of drug solutions must be clear, potentially free of particles, and osmolality must be compatible with blood.

What this study adds

- Current protocols have been for 0.5, 2,4 and $6 \mathrm{~g}$ of vancomycin infused continuously in syringes over 24 hours.

- For patients' safety, these solutions must be infused with a $0.2 \mu \mathrm{m}$ inline filter to limit particulate contamination.

more than $40 \mathrm{mg} / \mathrm{mL}$ of vancomycin reconstituted in saline solution and a $0.2 \mu \mathrm{m}$ inline filter must be used for infusion. The maximum concentration in a $20 \mathrm{~mL}$ vancomycin syringe should be $25 \mathrm{mg} / \mathrm{mL}$.

According to our reconstitution method, a clinical protocol can be applied to prepare vancomycin syringes with $0.2 \mu \mathrm{m}$ inline filters, if the SmPC is not applied, for the following dosages for 24 hours:

- $0.5 \mathrm{~g}(25 \mathrm{mg} / \mathrm{mL})$ : one $0.5 \mathrm{~g}$ vancomycin vial reconstituted with $10 \mathrm{~mL}$ of saline solution $+10 \mathrm{~mL}$ of saline solution as diluent, at a flow rate of $0.8 \mathrm{~mL} /$ hour. One syringe of $20 \mathrm{~mL}$ is required for 24 hours.

- $2 \mathrm{~g}(40 \mathrm{mg} / \mathrm{mL})$ : two $1 \mathrm{~g}$ vancomycin vials reconstituted each with $20 \mathrm{~mL}$ of saline solution $+10 \mathrm{~mL}$ of saline solution as diluent, at a flow rate of $2 \mathrm{~mL} /$ hour. One syringe of $50 \mathrm{~mL}$ is required for 24 hours.

- $3 \mathrm{~g}(30 \mathrm{mg} / \mathrm{mL})$ : one $1 \mathrm{~g}+$ one $0.5 \mathrm{~g}$ of vancomycin vials reconstituted with $20 \mathrm{~mL}$ of saline solution and $10 \mathrm{~mL}$ of saline solution, respectively $+20 \mathrm{~mL}$ of saline solution as diluent, at a flow rate of $4 \mathrm{~mL} /$ hour over 12 hours. Two syringes of $50 \mathrm{~mL}$ are required for 24 hours.

- $4 \mathrm{~g}(40 \mathrm{mg} / \mathrm{mL})$ : two $1 \mathrm{~g}$ vancomycin vials reconstituted each with $20 \mathrm{~mL}$ of saline solution $+10 \mathrm{~mL}$ of saline solution as diluent, at a flow rate of $4 \mathrm{~mL} /$ hour over 12 hours. Two syringes of $50 \mathrm{~mL}$ are required for 24 hours.

- $6 \mathrm{~g}(40 \mathrm{mg} / \mathrm{mL})$ : two $1 \mathrm{~g}$ vancomycin vials reconstituted each with $20 \mathrm{~mL}$ of saline solution $+10 \mathrm{~mL}$ of saline solution as diluent, at a flow rate of $6 \mathrm{~mL} /$ hour over 8 hours. Three syringes of $50 \mathrm{~mL}$ are required for 24 hours.

Twitter Morgane Masse @MorganeMasse

Acknowledgements We thank Alexandra Tavernier (MA, University of Glasgow, Professeur Agrégée, France) for English language and editing assistance.

Contributors Conception: MM, SG, CB, BD, PO. Formal analysis: MM, AMM, NC. Investigation: MM, AMM, NC. Methodology: MM, SG, CB, BD, PO. Supervision: SG, $C B, D L, B D, P O$. Writing the original draft and revision: $M M, A M M, N C, S G, D L, C B$, $\mathrm{BD}, \mathrm{PO}$.

Funding The authors have not declared a specific grant for this research from any funding agency in the public, commercial or not-for-profit sectors.

Competing interests None declared.

Patient consent for publication Not required.

Provenance and peer review Not commissioned; externally peer reviewed.

Data availability statement All data relevant to the study are included in the article or uploaded as supplementary information. 


\section{REFERENCES}

1 European Medicines Agency. Vancomycin, 2016. Available: http://www.ema. europa.eu/docs/en_GB/document_library/Referrals_document/Vancomycin_31/ WC500204131.pdf [Accessed Aug 2019].

2 van Hal SJ, Lodise TP, Paterson DL. The clinical significance of vancomycin minimum inhibitory concentration in Staphylococcus aureus infections: a systematic review and meta-analysis. Clin Infect Dis 2012;54:755-71.

3 Lundstrom TS, Sobel JD. Antibiotics for gram-positive bacterial infections: vancomycin quinupristin-dalfopristin, linezolid, and daptomycin. Infect Dis Clin North Am 2004;18:651-68.

4 San-Juan R, Fernández-Ruiz M, Gasch 0, et al. High vancomycin MICs predict the development of infective endocarditis in patients with catheter-related bacteraemia due to methicillin-resistant Staphylococcus aureus. J Antimicrob Chemother 2017;72:2102-9.

5 Longuet $\mathrm{P}$, Lecapitaine $\mathrm{AL}$, Cassard B, et al. Preparing and administering injectable antibiotics: how to avoid playing God. Med Mal Infect 2016;46:242-68.

6 Charmillon A, Novy E, Agrinier N, et al. The ANTIBIOPERF study: a nationwide cross-sectional survey about practices for $\beta$-lactam administration and therapeutic drug monitoring among critically ill patients in France. Clin Microbiol Infect 2016;22:625-31.

7 Godet M, Simar J, Closset M, et al. Stability of concentrated solution of vancomycin hydrochloride in syringes for intensive care units. Pharm Technol Hosp Pharm 2018:3:23-30.

8 Galanti LM, Hecq J-D, Vanbeckbergen D, et al. Long-term stability of vancomycin hydrochloride in intravenous infusions. J Clin Pharm Ther 1997;22:353-6.

9 Khalfi F, Dine T, Gressier B, et al. Compatibility and stability of vancomycin hydrochloride with PVC infusion material in various conditions using stabilityindicating high-performance liquid chromatographic assay. Int J Pharm 1996;139:243-7.

10 Raverdy V, Ampe E, Hecq J-D, et al. Stability and compatibility of vancomycin for administration by continuous infusion. J Antimicrob Chemother 2013;68:1179-82.

11 Habib G, Lancellotti P. Antunes MJ, et al. 2015 ESC guidelines for the management of infective endocarditis: the task force for the management of infective endocarditis of the European Society of cardiology (ESC). endorsed by: European association for Cardio-Thoracic surgery (EACTS), the European association of nuclear medicine (EANM). Eur Heart J 2015;36:3075-128.

12 Les méningites purulentes communautaires. 9ème Conférence de consensus en thérapeutique anti-infectieuse, 1996. Available: https://www.sfmu.org/upload/ consensus/cc_meningites_long.pdf [Accessed Aug 2019].

13 Résolution CM/Res. 2 sur les bonnes pratiques en matière de reconstitution, dans les établissements de santé, des médicaments destinés à un usage parentéral adoptée par le Comité des Ministres le 1er juin 2016 lors de la 1258e réunion des Délégués des Ministres, 2016. Available: https://www.edqm.eu/sites/default/files/resolution_ cm_res_2016-2_bonnes_pratiques_reconstitution_etablissements_de_sante medicaments_destines_a_un_usage_parenteral.pdf [Accessed Aug 2019].

14 Jesús Valle MJde, López FG, Navarro AS. Development and validation of an HPLC method for vancomycin and its application to a pharmacokinetic study. J Pharm Biomed Anal 2008;48:835-9.

15 SFPC, GERPAC. Methodological guidelines for stability studies of hospital pharmaceutical preparations, 2013. Available: http://www.gerpac.eu/IMG/pdf/guide stabilite_anglais.pdf [Accessed Aug 2019].

16 Hubert P, Nguyen-Huu J-J, Boulanger B, et al. Harmonization of strategies for the validation of quantitative analytical procedures. A SFSTP proposal--Part I. J Pharm Biomed Anal 2004;36:579-86.

17 Hubert P, Nguyen-Huu J-J, Boulanger B, et al. Harmonization of strategies for the validation of quantitative analytical procedures. J Pharm Biomed Anal 2007:45:82-96.

18 European Pharmacopoeia Commission. 2.9.19 Particulate contamination: subvisible particles Pharmacopoeia 9.5, 2018. https://www.edqm.eu/en/europeanpharmacopoeia-ph-eur-9th-edition. (accessed Aug 2019).

19 Drouet M, Chai F, Barthélémy C, et al. Influence of vancomycin infusion methods on endothelial cell toxicity. Antimicrob Agents Chemother 2015;59:930-4.

20 Summary of product characteristics of vancomycin, 2011. Available: http://basedonnees-publique. medicaments.gouv.fr/affichageDoc.php? specid $=66193112 \&$ typedoc $=R$ [Accessed Aug 2019].

21 Roethlisberger D, Mahler H-C, Altenburger U, et al. If Euhydric and isotonic do not work, what are acceptable $\mathrm{pH}$ and osmolality for parenteral drug dosage forms? $\mathrm{J}$ Pharm Sci 2017:106:446-56.

22 Foster BA, Tom D, Hill V. Hypotonic versus isotonic fluids in hospitalized children: a systematic review and meta-analysis. J Pediatr 2014;165:163-9.

23 McNearney T, Bajaj C, Boyars M, et al. Total parenteral nutrition associated crystalline precipitates resulting in pulmonary artery occlusions and alveolar granulomas. Dig Dis Sci 2003;48:1352-4.

24 Benlabed M, Perez M, Gaudy R, et al. Clinical implications of intravenous drug incompatibilities in critically ill patients. Anaesthesia Critical Care \& Pain Medicine 2019;38:173-80.

25 Luque Y, Louis K, Jouanneau C, et al. Vancomycin-Associated cast nephropathy. J Am SOc Nephrol JASN 2017;28:1723-8.

26 Lehr H-A, Brunner J, Rangoonwala R, et al. Particulate matter contamination of intravenous antibiotics aggravates loss of functional capillary density in postischemic striated muscle. Am J Respir Crit Care Med 2002;165:514-20.

27 Foinard A, Décaudin B, Simon N, et al. Vancomycin syringe study shows significant reduction in dosing variability after introducing a revised protocol. Acta Paediatr 2014; 103:e93-4. 